\title{
PENGARUH PEMBERDAYAAN KARYAWAN DAN STES KERJA TERHADAP KOMITMEN ORGANISASIONAL
}

\author{
I Made Hendra Adi $\mathbf{S}^{1}$ \\ I G.A Dewi Adnyani²
}

${ }^{1}$ Fakultas Ekonomi dan Bisnis Universitas Udayana (Unud), Bali, Indonesia email: hendrasucipta88@yahoo.com

\begin{abstract}
ABSTRAK
Penelitian ini bertujuan untuk menganalisis pengaruh pemberdayaan karyawan dan stres kerja terhadap komitmen organisasional pada rumah luwih hotel di keramas, gianyar. Lokasi penelitian ini dilakukan pada Rumah Luwih Hotel di Keramas Gianyar. Metode yang digunakan untuk menentukan sampel adalah teknik sampel jenuh atau sensus dan diperoleh sebanyak 40 sampel. Teknik analisis yang digunakan adalah analisis regresi linear berganda. Hasil penelitian menunjukkan bahwa pemberdayaan karyawan berpengaruh positif dan signifikan terhadap komitmen organisasional sedangkan 6448egati kerja berpengaruh 6448egative dan signifikan terhadap komitmen organisasional pada Rumah Luwih Hotel di Keramas Gianyar. Berdasarkan hasil ini, manajemen Rumah Luwih Hotel Di Keramas Gianyar diharapkan dapat memberdayakan karyawannya dengan melibatkan mereka dalam proses perencanaan serta karyawan hendaknya berkomunikasi kepada rekan dengan baik sehingga tidak merasa terbebani dengan pekerjaan yang berlebihan.
\end{abstract}

Kata kunci : pemberdayaan karyawan, stres kerja, komitmen organisasional

\section{ABSTRACT}

This study aims to analyze the influence of employee empowerment and work stress on organizational commitment at the hotel house in shampooing, Gianyar. The location of this research was conducted at Rumah Luwih Hotel in Keramas Gianyar. The method used to determine the sample is the technique of saturated samples or census and obtained as many as 40 samples. The analysis technique used is multiple linear regression analysis. The results of the study show that employee empowerment has a positive and significant effect on organizational commitment, while work ego has a significant and egalitarian effect on organizational commitment at Rumah Luwih Hotel in Keramas Gianyar. Based on these results, the management of Rumah Luwih Hotel in Keramas Gianyar is expected to empower its employees by involving them in the planning process and employees should communicate to colleagues well so they do not feel burdened with excessive work.

Keywords: employee empowerment, work stress, organizational commitment 


\section{PENDAHULUAN}

Pulau Bali merupakan barometer perkembangan pariwisata nasional yang memiliki destinasi pariwisata yang sangat terkenal di Indonesia bahkan ke mancanegara. Pariwisata menjadi sektor andalan utama bukan hanya oleh pemerintah daerah saja, bahkan lapisan masyarakat ikut andil di dalam meningkatkan perekonomian dengan bergerak di bidang industri pariwisata Bali. Sektor pariwisata merupakan sektor unggulan yang menjadi penyumbang Pendapatan Asli Daerah (PAD) di Bali.

Sektor pariwisata telah menjadi sektor yang memegang peranan penting dalam peningkatan perekonomian di Provinsi Bali. Untuk meningkatnya jumlah kunjungan wisatawan ke Indonesia pada umumnya dan Bali pada khususnya. Maka pemerintah lebih meningkatkan pada kualitas pelayanan dan fasilitasfasilitas yang memadai untuk menunjang peningkatan kunjungan wisatawan ke Bali. Bali sebagai pusat pariwisata Indonesia bagian tengah dan sebagai tujuan wisata dunia yang memiliki potensi menunjang pertumbuhan kepariwisataan. Perkembangan pembangunan kepariwisataan yang telah dicapai oleh pulau Bali sendiri terlihat pada jumlah kunjungan wisatawan mancanegara dan nusantara ke Bali pada Tabel 1.

Tabel 1.

Jumlah Kunjungan Wisatawan ke Bali

Tahun $2014-2018$

\begin{tabular}{lccccc}
\hline Bulan & $\mathbf{2 0 1 4}$ & $\mathbf{2 0 1 5}$ & $\mathbf{2 0 1 6}$ & $\mathbf{2 0 1 7}$ & $\mathbf{2 0 1 8}$ \\
\hline Januari & 279,257 & 301,748 & 350,592 & 460,824 & $358,065.00$ \\
Pebruari & 275,795 & 338,991 & 375,744 & 453,985 & $452,423.00$ \\
Maret & 276,573 & 305,272 & 364,113 & 425,499 & $492,678.00$ \\
April & 280,096 & 313,763 & 380,767 & 477,464 & $516,777.00$ \\
Mei & 286,033 & 295,973 & 394,557 & 489,376 & $528,512.00$ \\
Juni & 330,396 & 359,702 & 405,835 & 504,141 & $544,550.00$ \\
Juli & 361,066 & 382,683 & 484,231 & 592,046 & $624,366.00$ \\
Agustus & 336,763 & 303,621 & 438,135 & 601,884 & $573,766.00$ \\
September & 354,762 & 389,060 & 445,716 & 550,520 & $555,903.00$ \\
Oktober & 341,651 & 369,447 & 432,215 & 465,085 & $517,889.00$ \\
Nopember & 296,876 & 270,935 & 413,232 & 361,006 & $406,725.00$ \\
Desember & 347,370 & 370,640 & 442,800 & 315,909 & $498,819.00$ \\
Jumlah / Total : & $\mathbf{3 , 7 6 6 , 6 3 8}$ & $\mathbf{4 , 0 0 1 , 8 3 5}$ & $\mathbf{4 , 9 2 7 , 9 3 7}$ & $\mathbf{5 , 6 9 7 , 7 3 9}$ & $\mathbf{6 , 0 7 0 , 4 7 3}$ \\
Pertumbuhan / Growth (\%) & $\mathbf{1 4 . 8 9}$ & $\mathbf{6 . 2 4}$ & $\mathbf{2 3 . 1 4}$ & $\mathbf{1 5 . 6 2}$ & $\mathbf{6 . 5 4}$ \\
\hline Sumber: BPS Provin
\end{tabular}

Sumber: BPS Provinsi Bali, 2018

Tabel 1. menunjukkan bahwa tingkat kunjungan wisatawan ke Bali senantiasa mengalami peningkatan setiap tahunnya. Pertumbuhan kunjungan wisatawan melonjak di tahun 2016 yakni sebesar 23,14\%. Sementara dari tahun 2017 sampai dengan tahun 2018 tingkat pertumbuhan kunjungan wisatawan hanya meningkat sebesar $6,54 \%$. 
Seiring dengan perkembangan industri pariwisata, berbagai akomodasi pariwisata juga semain berkembang di Bali, mulai dari pembangunan Hotel, Villa, Restoran, serta akomodasi pariwisata lainnya. Industri jasa merupakan saah satu industri yang menghadapi persaingan sangat ketat. Penyedia jasa dituntut untuk senantiasa memberikan pelayanan prima bagi tamu (wisatawan) sehingga wisatawan mendapat kesan yang baik selama menggunkan jasa aomodasi di Bali. Salah satu elemen penting dalam menunjang pariwisata di Bali adalah keberadaan jasa akomodasi pariwisata. Keberhasilan perusahaan di bidang akomodasi khususnya hotel, sangat bergantung pada kemampuannya untuk memenuhi kebutuhan dan kepuasan tamu melalui para karyawan yang langsung berhadapan dengan tamu itu sendiri. Oleh karena itu, penting bagi manajemen hotel untuk membentuk sumber daya manusia yang memiliki komitmen organisasional yang tinggi agar dapat bersama-sama mewujudkan tujuan tersebut.

Seiring dengan kemajuan pariwisata, begitu banyak penyedia jasa akomodasi yang bermunculan hal inilah yang menjadikan persaingan pada industri jasa pariwisata khusunya hotel, villa. Restoran mengalami persaingan yang sangat ketat. Hal tersebut tentu senada dengan Tingkat Penghunian Kamar hotel (TPK) di hotel-hotel atau penyedia jasa akomodasi pariwisata di Bali. Adapun data TPK di Bali pada akhir bulan Desember 2018 adalah seperti pada Tabel 2.

Tabel 2.

Tingkat Penghunian Kamar (TPK) Hotel Berbintang di Bali Bulan Nopember s/d Desember 2018

\begin{tabular}{ccccc}
\hline No. & Kabupaten/Kota & Tingkat Penghunian Kamar (TPK) & Perubahan (Poin) \\
\hline 1 & Badung & 58,11 & 59,38 & 1,27 \\
2 & Gianyar & 44,70 & 48,32 & 3,63 \\
3 & Karangasem & 34,23 & 32,93 & $-1,30$ \\
4 & Bulelang & 34,99 & 37,13 & 2,14 \\
5 & Denpasar & 55,78 & 56,78 & 1,15 \\
& Bali & $\mathbf{5 5 , 9 2}$ & $\mathbf{5 7 , 6 2}$ & $\mathbf{1 , 7 0}$ \\
\hline
\end{tabular}

Sumber: BPS Provinsi Bali, 2018

Tabel 2. menunjukkan bahwa seiring dengan peningkatan jumlah kunjungan wisatawan juga berdampak pada peningkatan Tingkat Penghunian Kamar (TPK) Hotel di Provinsi Bali. Data pada Tabel 2 menunjukkan bahwa TPK tertinggi adalah pada hotel berbintang di Kabupaten Badung. Sementara TPK hotel terenda adalah di Kabupaten Karangasem. Sedangkan Kabupaten Gianyar merupakan Kabupaten dengan TPK tertinggi kedua di Bali.

Kabupaten Gianyar merupakan salah satu Kabupaten di Bali yang menjadi destinasi pariwisata khusunya wisata budaya. Gianyar dikenal sebagai kota seni, mulai dari seni tari, tabuh, pahat, ukir dan berbagai kesenian serta adat dan budaya menjadi magnet pariwisata di Kota Gianyar. Terdapat berbagai toiko produk kesenian (art shop), galeri, musem, villa serta hotel dan akomodasi pariwisata lainnya berkembang di daerah ini. Salah satunya adalah Rumah Luwih.

Rumah Luwih Hotel merupakan saah satu akomodasi jasa pariwisata berupa hotel yang dilengkapi dengan berbagai fasilitas penunjang pariwisata yang 
berloasi di Desa Keramas, Kabupaten Gianyar, Bali. Rumah Luwih Hotel di Keramas Gianyar memiliki fasilitas yang cukup lengkap dan berada dilokasi strategis. Rumah Luwih telah menjadi tempat pelaksanaan event fashion seperti peragaan busana yakni "Pergelaran Cinta Putih by Anna Avantie", menjadi salah satu tempat pernikahan (wedding venue), serta telah menjadi salah satu resort mewah (luxury resort) di Bali.

Sebagai sebuah perusahaan yang bergerak di bidang akomodasi dan jasa pariwisata, Rumah Luwih dituntut untuk senantiasa memberikan pelayanan yang prima pada seluruh layanan yang ditawarkan. Untuk itu, dukungan dan kerjasama yang baik antara pimpinan dan karyawan dalam menjalankan tugas sangat diharapkan untuk kemajuan perusahaan. Akan tetapi, berdasarkan wawancara dengan Baian Pengembangan Sumber Daya Manusia (Human Resource Development/HRD) Rumah Luwih menyatakan bahwa terdapat beberapa masalah yang berkaitan dengan komitmen organisasional karyawan di Rumah Luwih. Hal tersebut tampak dari rendanya tingkat kehadiran karyawan pada Rumah Luwih Hotel di Keramas Gianyar disajikan pada Tabel 3.

Tabel 3.

Tingkat Kehadiran Karyawan pada Rumah Luwih Hotel di Keramas, Kabupaten Gianyar

Bulan November 2017 s/d April 2018

\begin{tabular}{llrrrr}
\hline No. & Bulan & $\begin{array}{c}\text { Jumlah } \\
\text { Karyawan } \\
\text { (orang) }\end{array}$ & $\begin{array}{c}\text { Jumlah Hari } \\
\text { Kerja Seharusnya } \\
\text { (hari) }\end{array}$ & $\begin{array}{c}\text { Jumlah } \\
\text { Absensi Per } \\
\text { Bulan (hari) }\end{array}$ & $\begin{array}{c}\text { Persentase } \\
\text { Absensi (\%) }\end{array}$ \\
\hline 1. & November & 42 & 1092 & 164 & $15 \%$ \\
2. & Desember & 42 & 1008 & 144 & $14 \%$ \\
3. & Januari & 42 & 1092 & 151 & $14 \%$ \\
4. & Februari & 40 & 880 & 172 & $20 \%$ \\
$5 . \quad$ Maret & 40 & 1040 & 170 & $16 \%$ \\
$6 . \quad$ April & 40 & 1040 & 134 & $13 \%$ \\
Total & $\mathbf{5 2 5}$ & $\mathbf{4 8}$ & $\mathbf{2 1 0 0}$ & $\mathbf{5 2 1 7}$ \\
Rata-Rata & $\mathbf{8 7 , 5}$ & $\mathbf{2 5 , 0 0}$ & $\mathbf{1 . 0 2 5 , 3 3}$ & $\mathbf{1 5 \%}$ \\
\hline
\end{tabular}

Sumber: HRD Rumah Luwih Hotel di Keramas Gianyar, 2018

Tabel 3. menunjukkan Hasil perhitungan tingkat absensi karyawan Rumah Luwih Hotel di Keramas Gianyar menunjukkan bahwa rata-rata tingkat absensi karyawan sebesar $15 \%$, ini berarti bahwa tingkat absensi yang terjadi di perusahaan cukup tinggi. Ardana et al. (2012:52) menyatakan bahwa rata-rata tingkat absensi 2-3\% per bulan masih dianggap rendah, sedangkan tingkat absensi di atas $3 \%$ per bulan dianggap cukup tinggi. HRD Rumah Luwih menyatakan bahwa masalah lain yang dihadapi Rumah Luwih Hotel di Keramas Gianyar selain tingkat absensi adalah rendahnya loyalitas karyawan dan ketidakdisiplinan jam kerja yang dapat dilihat saat jam masuk kerja, dimana masih banyak terdapat karyawan yang jam kedatangannya terlambat 5-15 menit.

Berdasarkan wawancara awal yang dilakukan Peneliti terhadap 10 karyawan pada Rumah Luwih Hotel di Keramas Gianyar terungkap bahwa terdapat masalah terkait komitmen organisasional seperti karyawan tidak bersedia meluangkan waktu diluar jam kerja untuk kepentingan perusahaan, karyawan merasa ada 
perusahaan lain yang lebih menguntungkan, serta karyawan tidak merasa memiliki hutang budi terhadap perusahaan karena karyawan merasa semua yang diberikan perusahaan merupakan balas jasa yang diberikan karyawan kepada perusahaan.

Komitmen karyawan penting untuk dibangun agar meningkat karena dampak dari rendahnya komitmen organisasional adalah tingginya turnover pada karyawan, rendahnya kehadiran, kinerja, dan OCB pada karayawan (Meyer et al., 2002). Rendahnya komitmen organisasional mengakibatkan karyawan tidak berusaha dengan baik didalam mencapai tujuan organisasi. Lebih lanjut, Karambut \& Noormijati (2012) menyatakan tingginya komitmen organisasional akan berdampak pada karyawan yang akan memberikan usaha terbaik kepada organisasi, bahkan bersedia mengerjakan sesuatu melampaui batas yang diwajibkan organisasi.

Sumber daya manusia memiliki peranan yang sangat penting untuk perusahaan. Sumber daya manusia juga merupakan faktor penentu keberhasilan organisasi, untuk itu diperlukan sumber daya manusia yang memiliki skill, semangat kerja serta tanggung jawab yang tinggi dalam memberikan pelayanan yang maksimal. Yavuz (2010) berpendapat bahwa komitmen karyawan dalam perusahaan sangatlah penting karena komitmen karyawan akan berdampak positif terhadap sikap dan perilaku karyawan dalam mencapai tujuan perusahaan. Karambut \& Noormijati (2012) menyatakan bahwa karyawan yang memiliki komitmen terhadap perusahaan akan melakukan tugas dan kewajibannya dengan baik.

Faktor yang mempengaruhi komitmen organisasional yaitu pemberdayaan karyawan. Ismail et al. (2011) menyatakan bahwa pemberdayaan karyawan merupakan pendekatan yang demokratis dimana pimpinan mendorong karyawan untuk ikut terlibat dalam pengambilan keputusan yang bersangkutan dengan pekerjaan. Karyawan akan merasa nyaman jika perusahaan melibatkan dirinya dalam proses pengambilan keputusan. Menurut Elnaga \& Imran (2013) menyatakan bahwa perusahaan yang melakukan pemberdayaan karyawan akan mampu meningkatkan tanggung jawab karyawan. Dewi \& Utama (2015) menyatakan memberdayakan karyawan dalam perusahaan berarti memberikan kesempatan kepada karyawan untuk dapat menunjukkan potensi dan keterampilan yang dimilikinya. Jafari et al. (2013) dalam penelitiannya memperoleh hasil bahwa terdapat pengaruh positif dan signifikan antara pemberdayaan karyawan dan komitmen karyawan dalam organisasi.

Indikasi rendahnya pemberdayaan karyawan di Rumah Luwih Hotel di Keramas Gianyar perlu diperhatikan. Karyawan merasa bahwa atasan kurang percaya dengan potensi yang dimilikinya. Hal ini dapat dilihat dari pemberian tanggung jawab hanya pada satu karyawan dan tidak memberikan kesempatan kepada karyawan lain untuk terlibat. Selain pemberdayaan karyawan, terdapat faktor lain yang mempengaruhi komitmen organisasional yaitu stres kerja. Karyawan Rumah Luwih Hotel di Keramas Gianyar sering menerima beban kerja yang berlebihan sehingga pekerjaannya tidak mampu diselesaikan tepat waktu yang mengakitbatkan karyawan akan mengalami stres kerja. 
Stres kerja merupakan salah satu permasalahan yang sering dialami oleh karyawan di tempat kerjanya. Suhada et al. (2015) menyatakan konflik yang sering terjadi didalam sebuah perusahaan akan berakibat bagi rendahnya komitmen organisasional, karena tidak ada kenyamanan dengan lingkungan kerja yang dapat membuat karyawan meninggalkan perusahan.

Putra \& Wibawa (2014) mendefinisikan stres kerja adalah suatu kondisi karyawan yang mengalami tekanan dalam pekerjaan baik dari tugas, pimpinan dan lingkungan kerja tempat karyawan tersebut bekerja. Karambut \& Noormijati (2012) menjelaskan bahwa karyawan yang mengalami stres kerja akan cenderung tidak produktif kinerjanya. Hasibuan (2014:204) menyatakan orang-orang mengalami stress menjadi nervous dan merasakan kekhawatiran-kekhawatiran kronis sehingga mereka sering menjadi marah-marah, agresif, tidak dapat relaks, atau memperlihatkan sikap yang tidak kooperatif. Penelitian yang dilakukan oleh Harun et al. (2014) menunjukkan bahwa stres kerja berpengaruh negatif dan signifikan terhadap komitmen organisasi, karyawan yang memiliki tingkat stres tinggi akan berimplikasi pada rendahnya komitmen organisasional. Penelitian Harun et al. (2014) yang menunjukkan bahwa komitmen organisasional juga dipengaruhi oleh stres kerja, karyawan yang mendapatkan tingkat stres yang tinggi akan menyebabkan rendahnya komitmen organisasional.

Mohammadian \& Amirkabiri (2014) menyatakan bahwa pemberdayaan karyawan berpengaruh positif dan signifikan terhadap komitmen organisasional. Ismail et al. (2011) menyatakan bahwa pemberdayaan karyawan berkorelasi secara positif dan signifikan terhadap komitmen organisasional. Kuo et al. (2010) menyatakan bahwa pemberdayaan karyawan berpengaruh secara langsung dan positif terhadap komitmen karyawan dalam organisasi. Melalui kebijakan pemberdayaan karyawan yang tepat akan memberikan informasi yang berguna bagi pemimpin untuk meningkatkan komitmen karyawan terhadap pekerjaan dan organisasinya.

Bellingham (2003) menyatakan bahwa pemimpin etis ingin memberdayakan karyawan melalui pelatihan dan dukungan, mereka ingin memberikan kebebasan kepada karyawan mereka untuk menunjukkan inisiatif melalui tanggung jawab dan wewenang. Pemimpin etis mengajak pengikut mereka untuk bertimbang rasa melalui komunikasi terbuka (Brown \& Trevino, 2006) memperjelas apa tujuan organisasi dan apa yang diharapkan dari bawahan, sehingga menumbuhkan keterikatan karyawan dalam pekerjaan mereka (Macey et al., 2009). Brown et al. (2005) telah menunjukkan hubungan antara kepemimpinan etis dan teori pertukaran sosial. Dari sudut pandang karyawan, pemimpin etis adalah orang yang benar-benar dapat dipercaya. Pemimpin ini melalui pengambilan keputusan yang adil dan seimbang lebih jauh membentuk persepsi karyawan akan adanya hubungan pertukaran sosial (Mayer et al., 2009). Menurut Gouldner (1960) hubungan pertukaran sosial bergantung pada norma timbal balik. Misalnya, rasa kewajiban karyawan di tempat kerja sangat penting karena memaksa mereka untuk membayar imbalan bermanfaat yang diterima dari pimpinan mereka.

Teori pertukaran social (social exchange theory) menjelaskan tentang hubungan timbal balik karyawan dengan organisasi, organisasi yang memberikan karyawan dukungan dan mengakui pandangan karyawan dalam pengambilan 
keputusan, karyawan akan membalas dengan komitmen terhadap organisasi (Muhammad dan Abdullah, 2016). Pemberdayaan karyawan penting untuk dilakukan karena dampak dari adanya pemberdayaan karyawan dapat membuat karyawan merasa puas karena karyawan banyak berkontribusi dalam pencapaian tujuan organisasi yang mengarah pada tingginya komitmen organisasional (Diputri dan Rahyuda, 2016).

Conservation Of Resources (COR) Theory dikembangkan dari berbagai teori tentang penyebab stres. Cabang pengembangan COR kembali ke Walter Bradford Cannon (1932) yang merupakan salah satu peneliti pertama yang mempelajari konsep stres yang berlaku untuk manusia, khususnya dalam bagaimana stres dapat bertahan. Hans Selye (1950) mengambil penelitian Cannon tentang stres sebagai respons dan menunjukkan bahwa stres itu sendiri dirancang sebagai cara untuk melindungi tubuh dari tantangan lingkungan.

Peneliti lain seperti Elliot dan Eisdorfer (1982) mendefinisikan stres secara khusus sebagai stimulus dan bukan respons, yang telah diterima oleh beberapa komunitas ilmiah. Namun, teori ini sebagian besar didasarkan pada model stres homeostatik yang dikembangkan oleh Joseph McGrath (1970). Dalam teori inilah stres didefinisikan sebagai ketidakseimbangan antara permintaan lingkungan dan kemampuan respons suatu organisme.

Prinsip kedua dalam conversation of esources (COR) dikenal sebagai Investasi Sumber Daya. Prinsip COR ini menyatakan bahwa orang akan cenderung menginvestasikan sumber daya untuk melindungi dari kehilangan sumber daya, untuk pulih dari kerugian, dan untuk mendapatkan sumber daya. Dalam konteks mengatasi, orang akan menginvestasikan sumber daya untuk mencegah kerugian sumber daya di masa depan. Dari dua prinsip ini, COR telah menyarankan sejumlah konsekuensi wajar yang dapat diterapkan pada perubahan sumber daya. Mereka adalah. 1. Individu dengan sumber daya yang lebih tinggi akan diatur untuk memperoleh sumber daya. Demikian pula, individu dengan sumber daya lebih sedikit lebih mungkin mengalami kehilangan sumber daya. 2. Kehilangan sumber daya awal akan menyebabkan hilangnya sumber daya di masa depan. 3 . Keuntungan sumber daya awal akan menyebabkan peningkatan sumber daya di masa depan. 4. Kurangnya sumber daya akan selalu mengarah pada upaya defensif untuk melestarikan sumber daya yang tersisa.

COR telah digunakan ketika mempelajari stres kerja/keluarga, kelelahan, dan stres umum. Dalam tekanan pekerjaan/keluarga, penelitian COR telah melihat bagaimana distribusi sumber daya seseorang telah memengaruhi kehidupan rumah mereka, dengan beberapa artikel menemukan bahwa menempatkan terlalu banyak sumber daya seseorang ke dalam pekerjaan seseorang dapat menyebabkan masalah keluarga di rumah. Penelitian terhadap COR dan burnout telah meneliti bagaimana penggunaan sumber daya telah memengaruhi suasana hati seseorang, dengan penelitian baru-baru ini menemukan bahwa kelelahan emosional memiliki hubungan yang paling kuat dengan gejala depresi. Sehubungan dengan stres umum, penelitian telah mengeksplorasi bagaimana hilangnya sumber daya berdampak pada tingkat stres seseorang. Perlu dicatat bahwa COR terutama telah dipelajari dalam burnout dan bidang pekerjaan, seperti yang ditunjukkan oleh meta-analisis berikut. Saat ini tidak ada meta-analisis pada COR dalam bidang 
penelitian stres lainnya. Berbagai meta-analisis telah dilakukan dengan COR, khususnya terkait dengan burnout. Satu meta-analisis oleh Lee dan Ashforth (1996) meneliti hubungan antara permintaan dan sumber daya berkorelasi, perilaku dan berkorelasi sikap, dan 3 dimensi yang berbeda dari kelelahan kerja. Ini menggunakan COR sebagai dasar untuk penelitian ini dan menemukan bahwa keunggulan prinsip kehilangan sumber daya didukung. Ditemukan bahwa, lebih dari 58 sumber, individu cenderung lebih sensitif terhadap peningkatan permintaan daripada sumber daya yang diterima. Kontrol pekerjaan dan COR telah dipelajari melalui meta-analisis yang dilakukan oleh Park, Baiden, Jacob, \& Wagner (2009). Penelitian ini menguji COR menggunakan semua konstruk yang terlibat dalam kontrol pekerjaan dan kejenuhan yang mencakup konstruk otonomi, wewenang, keleluasaan keterampilan, dan lintang keputusan. Hasil menunjukkan bahwa konstruk kontrol pekerjaan, atau kemampuan seseorang untuk memilih tindakan dari berbagai opsi di pekerjaannya, terkait dengan depersonalisasi dan pencapaian pribadi. Studi ini menyatakan bahwa COR terkait dengan kelelahan dengan cara ini, tetapi studi lebih lanjut harus dilakukan yang menggunakan pekerjaan layanan non-manusia.

Conservation Of Resources (COR) Theory yang dikembangkan oleh Stevan Hobfoll, teori yang menjelaskan seseorang akan berusaha untuk memperoleh dan menjaga atau mempertahankan sumber daya yang dimilikinya, sumber daya disini meliputi energi (waktu) (Dewe et al., 2012). Waktu merupakan hal yang penting yang dibutuhkan oleh karyawan didalam melakukan pekerjaan, karyawan yang memiliki waktu yang terbatas dan dituntut melakukan pekerjaan yang sangat banyak, akan membuat karyawan kehilangan sumber daya tersebut dan mengakibatkan keadaan negatif, seperti mengalami stres. Stres yang tinggi akan membuat komitmen karyawan terhadap organisasi menurun, sebaliknya kondisi yang menguntungkan akan menyebabkan keuntungan sumber daya, ketika karyawan merasa ada suasana tenang dan nyaman di tempat bekerja karena pekerjaan tidak dikejar oleh waktu, mereka akan merasa senang didalam menghabiskan sisa karirnya di organisasi dan akan meningkatkan komitmen organisasional.

Rumah Luwih merupakan salah satu akomodasi pariwisata yang ada di Desa Keramas Kabupaten Gianyar Provinsi Bali. Berbagai fasilitas ditawarkan di Rumah Luwih Hotel dan berbagai event-event bertaraf nasional dan internasional pernah dilakukan disini. Namun, berdasarkan wawancara awal Peneliti dengan bagian pengembangan Sumber Daya Manusia (Human Resources Development/HRD) menyatakan bahwa loyalitas karyawan di Rumah Luwih hotel masih termasuk kategori rendah yang ditandai oleh tingginya tingkat ketidakhadiran atau absensi karyawan Rumah Luwih. Setiawan dan Piartrini (2018) menyatakan bahwa pemberdayaan karyawan dan stress kerja merupakan salah satu faktor yang mempengaruhi komitmen organisasional.

Berdasarkan uraian tersebut diatas, peneliti membuat kerangka konseptual yang menggambarkan penelitian ini, kerangka konseptual menjelaskan secara teoritis pertautan antar variabel yang akan diteliti yakni terdiri dari variabel dependen dan independen (Sekaran, 2009). Kerangka konseptual dalam penelitian ini dapat digambarkan sebagai berikut: 


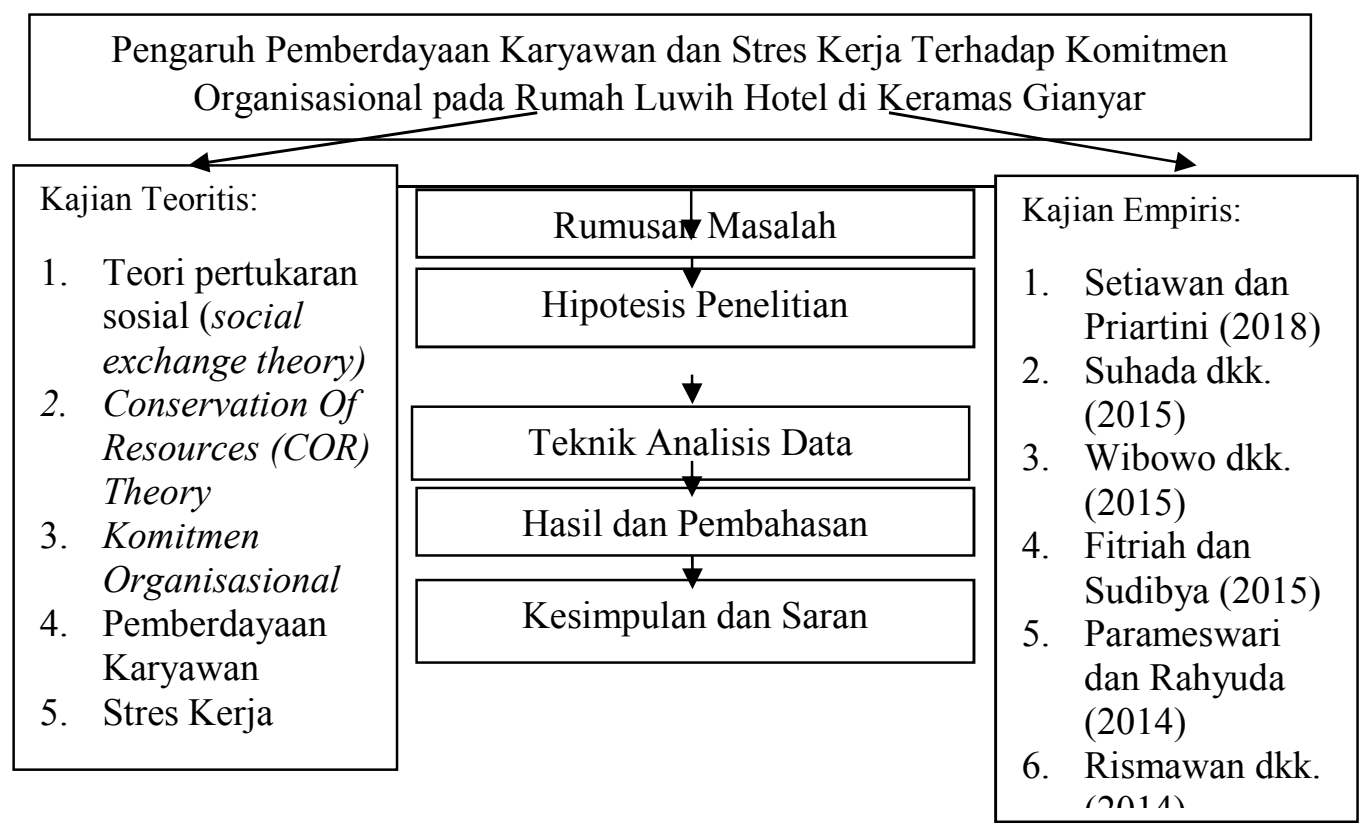

\section{Gambar 1. Kerangka Konseptual}

Pengaruh Pemberdayaan Karyawan Terhadap Komitmen Organisasional dijelaskan oleh teori pertukaran social (social exchange theory). Teori pertukaran social (social exchange theory) menjelaskan tentang hubungan timbal balik karyawan dengan organisasi, organisasi yang memberikan karyawan dukungan dan mengakui pandangan karyawan dalam pengambilan keputusan, karyawan akan membalas dengan komitmen terhadap organisasi (Muhammad \& Abdullah, 2016). Lebih lanjut, Diputri \& Rahyuda (2016) pemberdayaan karyawan penting untuk dilakukan karena dampak dari adanya pemberdayaan karyawan dapat membuat karyawan merasa puas karena karyawan banyak berkontribusi dalam pencapaian tujuan organisasi yang mengarah pada tingginya komitmen organisasional.

Abdullah et al. (2015) menyatakan pemberdayaan dapat dilihat sebagai cara untuk mendorong komitmen individu untuk organisasi karena meningkatkan kesesuaian antara peran kerja dan kepercayaan diri dalam kemampuan individu untuk melakukan pekerjaan dengan baik dan mendorong karyawan untuk melakukan upaya lebih atas nama organisasi dan lebih berpartisipasi dalam pengambilan keputusan. Mohammadian \& Amirkabiri (2014) menyatakan bahwa pemberdayaan karyawan berpengaruh positif dan signifikan terhadap komitmen oraganisasional.

Mohammadian \& Amirkabiri (2014) menyatakan bahwa pemberdayaan karyawan berpengaruh positif dan signifikan terhadap komitmen organisasional. Ismail et al. (2011) menyatakan bahwa pemberdayaan karyawan berkorelasi secara positif dan signifikan terhadap komitmen organisasional. Kuo et al. (2010) menyatakan bahwa pemberdayaan karyawan berpengaruh secara langsung dan 
positif terhadap komitmen karyawan dalam organisasi. Melalui kebijakan pemberdayaan karyawan yang tepat akan memberikan informasi yang berguna bagi pemimpin untuk meningkatkan komitmen karyawan terhadap pekerjaan dan organisasinya.

Jafari et al. (2013) dalam penelitiannya terhadap 126 karyawan memperoleh hasil bahwa terdapat pengaruh positif dan signifikan antara pemberdayaan karyawan dan komitmen karyawan dalam organisasi. Parameswari \& Rahyuda (2014) menyatakan bahwa pemberdayaan karyawan berpengaruh positif dan signifikan terhadap komitmen organisasional. Pratiwi (2012) menyatakan bahwa pemberdayaan berpengaruh positif terhadap komitmen organisasional. Berdasarkan beberapa penelitian sebelumnya maka dapat dirumuskan hipotesis sebagai berikut:

$\mathrm{H}_{1}$ : Pemberdayaan karyawan berpengaruh positif terhadap komitmen organisasional.

Pengaruh Stres Kerja Terhadap Komitmen Organisasional dapat dijelaskan oleh Conservation of Resources (COR) theory. Dewe et al. (2012) menjelaskan bahwa Conservation of Resources (COR) theory merupakan sebuah teori yang dikembangkan oleh Stevan Hobfoll, teori yang menjelaskan seseorang akan berusaha untuk memperoleh dan menjaga atau mempertahankan sumber daya yang dimilikinya, sumber daya disini meliputi energi (waktu). Waktu merupakan hal yang penting yang dibutuhkan oleh karyawan didalam melakukan pekerjaan, karyawan yang memiliki waktu yang terbatas dan dituntut melakukan pekerjaan yang sangat banyak, akan membuat karyawan kehilangan sumber daya tersebut dan mengakibatkan keadaan negatif, seperti mengalami stres. Stres yang tinggi akan membuat komitmen karyawan terhadap organisasi menurun, sebaliknya kondisi yang menguntungkan akan menyebabkan keuntungan sumber daya, ketika karyawan merasa ada suasana tenang dan nyaman di tempat bekerja karena pekerjaan tidak dikejar oleh waktu, mereka akan merasa senang didalam menghabiskan sisa karirnya di organisasi dan akan meningkatkan komitmen

Mohammadian \& Amirkabiri (2014) menyatakan bahwa stres kerja berpengaruh negatif dan signifikan terhadap komitmen organisasional. Hal ini berarti bahwa semakin tinggi stress kerja, maka komitmen organisasional semakin kecil. Harun et al. (2014) menyatakan bahwa stres kerja memiliki hubungan negatif yang signifikan dengan komitmen organisasional. Hubungan negatif antara stres kerja dengan komitmen organisasional, berarti bahwa karyawan yang memiliki tingkat stres tinggi berimplikasi terhadap rendahnya komitmen organisasional mereka. Hasil tersebut sejalan dengan hasil penelitian Iresa et al. (2015) yang menyatakan bahwa stres kerja memiliki hubungan yang negatif dan signifikan dengan komitmen organisasional. Pengaruh negatif dan signifikan menunjukkan hubungan dimana ketika stress kerja yang diaami oleh karyawan semakin meningkat, maka hal tersebut malah akan menurunkan komitmen organisasional. Hal senada juga dinyatakan oleh Wibowo et al. (2015), dalam penelitiannya menemukan bahwa stres kerja berpengaruh negatif terhadap komitmen organisasional. Hal ini bermakna bahwa stres kerja yang dialami oleh karyawan dapat mempengaruhi persepsi mereka terhadap keselarasan antara tujuan dan nilai individu dengan organisasi. Karambut \& Noormijati (2012) 
memperoleh hasil bahwa arah hubungan negatif antara stres kerja dan komitmen organisasi menunjukkan bahwa tingkat stres kerja yang rendah cenderung diikuti dengan peningkatan komitmen organisasi, semakin rendah stres kerja seseorang maka akan semakin tinggi komitmen organisasional mereka.

Abdullah et al. (2015) menyatakan pemberdayaan dapat dilihat sebagai cara untuk mendorong komitmen individu untuk organisasi karena meningkatkan kesesuaian antara peran kerja dan kepercayaan diri dalam kemampuan individu untuk melakukan pekerjaan dengan baik dan mendorong karyawan untuk melakukan upaya lebih atas nama organisasi dan lebih berpartisipasi dalam pengambilan keputusan. Mohammadian dan Amirkabiri (2014) menyatakan bahwa pemberdayaan karyawan berpengaruh positif dan signifikan terhadap komitmen oraganisasional.

Mohammadian dan Amirkabiri (2014) menyatakan bahwa pemberdayaan karyawan berpengaruh positif dan signifikan terhadap komitmen organisasional. Ismail et al. (2011) menyatakan bahwa pemberdayaan karyawan berkorelasi secara positif dan signifikan terhadap komitmen organisasional. Kuo et al. (2010) menyatakan bahwa pemberdayaan karyawan berpengaruh secara langsung dan positif terhadap komitmen karyawan dalam organisasi. Melalui kebijakan pemberdayaan karyawan yang tepat akan memberikan informasi yang berguna bagi pemimpin untuk meningkatkan komitmen karyawan terhadap pekerjaan dan organisasinya.

Jafari et al. (2013) dalam penelitiannya terhadap 126 karyawan memperoleh hasil bahwa terdapat pengaruh positif dan signifikan antara pemberdayaan karyawan dan komitmen karyawan dalam organisasi. Parameswari dan Rahyuda (2014) menyatakan bahwa pemberdayaan karyawan berpengaruh positif dan signifikan terhadap komitmen organisasional. Pratiwi (2012) menyatakan bahwa pemberdayaan berpengaruh positif terhadap komitmen organisasional.

Berdasarkan beberapa penelitian sebelumnya maka dapat dirumuskan hipotesis sebagai berikut:

$\mathrm{H}_{2}$ : Stres kerja berpengaruh negatif terhadap komitmen organisasional

\section{METODE PENELITIAN}

Lokasi penelitian ini adalah pada Rumah Luwih Hotel di Keramas Gianyar. Lokasi ini dipilih karena ditemukan masalah-masalah mengenai komitmen organisasional dari karyawan, dimana diduga komitmen organisasional karyawan dipengaruhi oleh pemberdayaan karyawan dan stres kerja. Selain itu lokasi pemilihan didasarkan atas tersedianya data yang memadai dan mampu untuk diolah.

Populasi adalah wilayah generalisasi terdiri atas obyek/subyek yang mempunyai kualitas dan karakteristik tertentu ditetapkan oleh peneliti untuk dipelajari dan kemudian ditarik kesimpulan, dalam penelitian ini adalah seluruh karyawan Rumah Luwih Hotel di Keramas Gianyar yang berjumlah 40 orang,

Penelitian ini memakai metode analisis regresi linear berganda yang nantinya berguna sebagai alat guna mencari tahu pengaruh variabel bebas atau independen dengan variabel terikat atau dependen. Variabel bebas atau variabel independen yang merupakan variabel yang mempengaruhi di dalam penelitian ini 
yaitu variabel pemberdayaan karyawan (X1) dan stres kerja (X2), sedangkan variabel terikat atau variabel dependen yang merupakan variabel yang dipengaruhi di dalam penelitian ini adalah komitmen organisasional (Y).

Adapun model regresi linear berganda yang dapat dijabarkan dengan menggunakan persamaan sebagai berikut:

$\mathrm{Y}=\mathrm{a}+\beta 1 \mathrm{X} 1+\beta 2 \mathrm{X} 2+\mathrm{e}$

Keterangan:

$$
\begin{array}{ll}
\mathrm{a} & =\text { Konstanta } \\
\beta 1-\beta 2 & =\text { Koefisien regresi } \\
\mathrm{Y} & =\text { Komitmen Organisasional } \\
\mathrm{X} 1 & =\text { Pemberdayaan Karyawan } \\
\mathrm{X} 2 & =\text { Stres Kerja } \\
\mathrm{e} & =\text { Error }
\end{array}
$$

\section{HASIL DAN PEMBAHASAN}

Rumah Luwih, yang terletak di kawasan Keramas Gianyar, Bali. Letaknya yang sangat strategis yakni Kuta hanya berjarak $25.7 \mathrm{~km}$ dari Rumah Luwih Beach Resort and Spa, serta Ubud berjarak $12.9 \mathrm{~km}$. Bandara Ngurah Rai berjarak $27.4 \mathrm{~km}$. Rumah Luwih Beach Resort and Spa adalah salah satu resort mewah (luxury resort) di Bali. Adapun visi dan misi Rumah Luwih Hotel di Keramas Gianyar adalah.Visi, Menjadi organisasi yang menyediakan pelayanan perhotelan secara global dan pengalaman, yang berfokus pada kesempurnaan, tanggung jawab dan berkelanjutan untuk berkontribusi bagi dunia yang lebih baik. Misi, Memberikan pelayanan terbaik kepada tamu, melakukan segala sesuatu dengan benar, secara profesional, efisien, dan cepat, berinovasi dan berevolusi untuk menjadi semakin baik setiap hari, memberikan kenyamanan bagi karyawan

\begin{tabular}{|c|c|c|c|c|c|c|}
\hline \multicolumn{7}{|c|}{ Coefficients ${ }^{a}$} \\
\hline & \multirow[t]{2}{*}{ Model } & \multicolumn{2}{|c|}{$\begin{array}{l}\text { Unstandardized } \\
\text { Coefficients }\end{array}$} & \multirow{2}{*}{$\begin{array}{c}\text { Standardized } \\
\text { Coefficients } \\
\text { Beta }\end{array}$} & \multirow[t]{2}{*}{$\mathbf{t}$} & \multirow[t]{2}{*}{ Sig. } \\
\hline & & B & Std. Error & & & \\
\hline \multirow{3}{*}{1} & (Constant) & 13.076 & 2.570 & & 5.089 & .000 \\
\hline & $\begin{array}{l}\text { Pemberdayaan } \\
\text { Karyawan (X1) }\end{array}$ & 1.509 & .152 & .870 & 9.929 & .000 \\
\hline & StresKerja (X2) & -.250 & .104 & -.210 & -2.392 & .022 \\
\hline
\end{tabular}
dengan saling berbagi, mendengarkan

Berikut adalah hasil analisis regresi linier berganda disajikan dalam tabel 4 di bawah ini:

Tabel 4.

Analisis Regresi Linier Berganda

Sumber: Data diolah, 2018

Berdasarkan Tabel 4. dapat dilihat bahwa besarnya nilai $\mathrm{R}$ square adalah sebesar 0,727 ini berarti pengaruh variabel Pemberdayaan Karyawan dan Stres Kerja terhadap Komitmen Organisasional sebesar 72,7 persen sedangkan sisanya 
sebesar 27,3 persen dipengaruhi oleh variabel lain yang tidak masuk dalam model penelitian. Pada tabel 4.10 dapat dilihat nilai koefisien regresi dari variabel bebas Pemberdayaan Karyawan dan Stres Kerja dan konstanta variabel terikat (Komitmen Organisasional), maka diperoleh persamaan regresi linier berganda sebagai berikut:

$$
\mathrm{Y}=13.076+1,509(\mathrm{X} 1)+-0,250(\mathrm{X} 2)+\mathrm{e}
$$

Berdasarkan persamaan tersebut, maka variabel Pemberdayaan Karyawan dan Stres Kerja berpengaruh terhadap Komitmen Organisasional pada karyawan Rumah Luwih Hotel Di Keramas Gianyar. Diketahui konstanta besarnya 13.076 mengandung arti jika variabel Pemberdayaan Karyawan (X1) dan Stres Kerja (X2) tidak berubah, maka Komitmen Organisasional (Y) tidak mengalami perubahan atau sama dengan 13.076.

Tabel 5.

Hasil Uji Hipotesis (Uji F)

\begin{tabular}{llrrrrr}
\hline Model & & Sum of Squares & Df & Mean Square & F & Sig. \\
\hline \multirow{3}{*}{1} & Regression & 952.014 & 2 & 476.007 & 49.367 & $.000^{\mathrm{b}}$ \\
& Residual & 356.761 & 37 & 9.642 & & \\
& Total & 1308.775 & 39 & & & \\
\hline
\end{tabular}

Sumber: Data diolah, 2018

Berdasarkan Tabel 5, maka hasil uji $\mathrm{F}$ dalam penelitian ini adalah $\mathrm{F}$ hitung sebesar 49.367 dengan nilai signifikan $0,000<0,05$ maka Ho ditolak. Ini berarti variabel Pemberdayaan Karyawan dan Stres Kerja berpengaruh secara simultan terhadap variabel Komitmen Organisasional pada karyawan Rumah Luwih Hotel di Keramas Gianyar.

Uji t dilakukan untuk melihat pengaruh variabel Pemberdayaan Karyawan dan Stres Kerja terhadap variabel Komitmen Organisasional secara parsial. Pada Tabel 2 dapat dilihat hasil uji-t dengan program SPSS.

Tabel 6.

Hasil Uji-t

\begin{tabular}{cccc}
\hline No & \multicolumn{1}{c}{ Variabel } & thitung & Signifikansi \\
\hline 1. & Pemberdayaan Karyawan & 9,929 & 0,000 \\
2. & Stres Kerja & $-2,392$ & 0,022 \\
\hline \multicolumn{2}{l}{ Sumber: } & Data diolah, 2018
\end{tabular}

Oleh karena thitung sebesar 9,929 dengan nilai signifikan $0,000<\alpha(0,05)$ maka $\mathrm{H}_{0}$ ditolak. Hal ini berarti variabel Pemberdayaan berpengaruh positif signifikan secara parsial terhadap variabel Komitmen Organisasional pada karyawan Rumah Luwih Hotel di Keramas Gianyar.

Oleh karena thitung sebesar -2,392 dengan nilai sig $0,022<\alpha(0,05)$ maka $\mathrm{H}_{0}$ ditolak. Hal ini berarti variabel Stres Kerja berpengaruh negatif signifikan secara parsial terhadap variabel Komitmen Organisasional pada karyawan Rumah Luwih Hotel Di Keramas Gianyar. 
Hasil pengujian hipotesis menunjukkan bahwa terdapat pengaruh yang positif dan signifikan variabel Pemberdayaan Karyawan terhadap Komitmen Organisasional pada karyawan Rumah Luwih Hotel Di Keramas Gianyar, artinya peningkatan pada Pemberdayaan Karyawan akan diikuti oleh peningkatan pada Komitmen Organisasional. Hasil penelitian ini sejalan dengan penelitian yang dilakukan oleh Mohammadian \& Amirkabiri (2014) menyatakan bahwa pemberdayaan karyawan berpengaruh positif dan signifikan terhadap komitmen organisasional. Ismail et al. (2011) menyatakan bahwa pemberdayaan karyawan berkorelasi secara positif dan signifikan terhadap komitmen organisasional. Kuo et al. (2010) menyatakan bahwa pemberdayaan karyawan berpengaruh secara langsung dan positif terhadap komitmen karyawan dalam organisasi.

Hasil penelitian ini juga didukung dengan penelitian sebelumnya yakni penelitian Fitriah \& Sudibya (2015), Gunawan \& Viyanita (2012), Karim \& Rehman (2012), Kazlauskaite et al. (2011), Parameswari \& Rahyuda (2014), Pratiwi (2012), Ramdhan (2015), Tielung (2013), Wadhwa \& Verghese (2015), dan Yusuf (2013).

Melalui kebijakan pemberdayaan karyawan yang tepat akan memberikan informasi yang berguna bagi pemimpin untuk meningkatkan komitmen karyawan terhadap pekerjaan dan organisasinya. Jafari et al. (2013) dalam penelitiannya memperoleh hasil bahwa terdapat pengaruh positif dan signifikan antara pemberdayaan karyawan dan komitmen karyawan dalam organisasi. Parameswari \& Rahyuda (2014) menyatakan bahwa pemberdayaan karyawan berpengaruh positif dan signifikan terhadap komitmen organisasional. Pratiwi (2012) menyatakan bahwa pemberdayaan berpengaruh positif terhadap komitmen organisasional.

Hasil pengujian hipotesis menunjukkan bahwa terdapat pengaruh yang positif dan signifikan variabel Stres Kerja terhadap Komitmen Organisasional pada karyawan Rumah Luwih Hotel Di Keramas Gianyar, artinya peningkatan pada Stres Kerja maka akan menyebabkan menurunnya Komitmen Organisasional. Hasil penelitian ini sejalan dengan penelitian yang dilakukan oleh Mohammadian \& Amirkabiri (2014) menyatakan bahwa stress kerja berpengaruh negatif dan signifikan terhadap komitmen organisasional. Harun et al. (2014) menyatakan bahwa stress kerja memiliki hubungan negatif yang signifikan dengan komitmen organisasional.

Iresa et al. (2015) menyatakan bahwa stress kerja memiliki hubungan yang negatif dan signifikan dengan komitmen organisasional. Wibowo et al. (2015) dalam penelitiannya menemukan bahwa stres kerja berpengaruh negatif terhadap komitmen organisasional. Karambut \& Noormijati (2012) memperoleh hasil bahwa arah hubungan negatif antara stres kerja dan komitmen organisasi menunjukkan bahwa tingkat stres kerja yang rendah cenderung diikuti dengan peningkatan komitmen organisasi, semakin rendah stres kerja seseorang maka akan semakin tinggi komitmen organisasional mereka. Hasil penelitian ini juga didukung oleh hasil penelitian sebelumnya yang dilakukan oleh Karambut \& Noormijati (2012), Kristin \& Sadjiarto (2014), Rismawan et al. (2014), Suhada et al. (2015), dan Wibowo et al. (2015). 
Implementasi penelitian ini mencakup dua hal yaitu, implikasi teoritis dan implikasi praktis yang menekankan pada manfaat nyata dari hasil penelitian untuk meningkatkan komitmen organisasional karyawan Rumah Luwih Hotel di Keramas Gianyar melalui peningkatakn pemberdayaan karyawan.

Beberapa implikasi hasil penelitian ini adalah 1. Implikasi Teoritis hasil penelitian ini tidak dapat membuktikan teori yang digunakan dalam penelitian ini yaitu teori teori pertukaran sosial (Social Exchange) dan Conservation of Resources (COR) theory. Penelitian ini juga dapat menambah referensi, informasi, wawasan, dan memberikan pemahaman yang lebih luas berkaitan dengan komitmen organisasiona, pemberdayaan karyawan dan stress kerja, 2. Implikasi Praktis hasil penelitian ini diharapkan akan memberikan kontribusi positif bagi pihak-pihak yang berkepentingan, utanya pihak manajemen Rumah Luwih Hotel di Keramas Gianyar mengenai pentingnya program pemberdayaan karyawan dan pengelolaan stress kerja karyawan, sehingga komitmen organisasional di Rumah Luwih Hotel dapat mengalami peningkatan. Perusahaan hendaknya memperhatikan bagaimana pemberdayaan karyawan agar komitmen organisasional tidak rendah dengan cara memberikan seperti motivasi kerja sehingga mampu tercapainya tujuan perusahaan.

Respon karyawan terhadap berbagai aspek pemberdayaan karyawan menunjukkan sebagian besar karyawan memiliki komitmen organisasional yang rendah, karyawan menganggap jarang bertanggung jawab untuk hasil kerja yang dilakukan, jarang memberikan usulan untuk pemecahan terhadap masalah yang ada dalam organisasi, jarang memiliki kebebasan memutuskan bagaimana melakukan pekerjaan, jarang memperoleh data dan informasi terkait pekerjaan dengan mudah, jarang terlibat ketika mendiskusikan perubahan didalam organisasi, jarang ikut terlibat didalam menentukan tujuan organisasi, jarang memiliki otonomi dalam menentukan cara kerja, jarang terlibat didalam pengambilan keputusan terkait tugas pokok.

Kondisi tersebut tentunya harus mendapatkan perhatian yang lebih bagi pihak manajemen hotel (Rumah Luwih Hotel) dengan memperhatikan aspek yang dinyatakan oleh karyawan dengan memberikan tanggung jawab pada karyawan untuk hasil kerja yang dilakukannya, memberikan karyawan kesempatan untuk memberi usulan didalam pemecahan masalah yang ada didalam organisasi, memberikan karyawan kebebasan memutuskan bagaimana melakukan pekerjaan, memberikan karyawan data dan informasi terkait pekerjaan dengan mudah, melibatkan karyawan didalam mendiskusikan setiap perubahan yang ada di organisasi, mengikut sertakan karyawan didalam menentukan tujuan dan target atau capaian yang diinginkan oleh organisasi, memberikan karyawan otonomi dalam menentukan cara kerja, melibatkan karyawan didalam pengambilan keputusan terkait tugas pokok sehingga dapat meningkatkan komitmen organisasional karyawan di Rumah Luwih Hotel di Keramas, Gianyar.

Hasil penelitian ini tidak dapat membuktikan teori yang digunakan dalam penelitian ini yaitu teori teori pertukaran sosial (Social Exchange) dan Conservation of Resources (COR) theory. Penelitian ini juga dapat menambah referensi, informasi, wawasan, dan memberikan pemahaman yang lebih luas 
berkaitan dengan komitmen organisasional, pemberdayaan karyawan dan stress kerja.

Hasil penelitian ini diharapkan akan memberikan kontribusi positif bagi pihak-pihak yang berkepentingan, utanya pihak manajemen Rumah Luwih Hotel di Keramas Gianyar mengenai pentingnya program pemberdayaan karyawan dan pengelolaan stress kerja karyawan, sehingga komitmen organisasional di Rumah Luwih Hotel dapat mengalami peningkatan. Perusahaan hendaknya memperhatikan bagaimana pemberdayaan karyawan agar komitmen organisasional tidak rendah dengan cara memberikan seperti motivasi kerja sehingga mampu tercapainya tujuan perusahaan.

Penelitian ini memiliki keterbatasan yaitu jumlah responden hanya 40 karyawan dan hanya dari lingkungan Rumah Luwih Hotel di Keramas, Gianyar, sehingga hasil penelitian ini hanya dapat diterapkan dilingkungan Rumah Luwih Hotel di Keramas, Gianyar dan tidak dapat digeneralisir pada lingkungan hotel/villa lain

\section{SIMPULAN}

Hasil pengujian hipotesis menunjukkan bahwa terdapat pengaruh yang positif dan signifikan variabel Pemberdayaan Karyawan terhadap Komitmen Organisasional pada karyawan Rumah Luwih Hotel Di Keramas Gianyar, yang artinya peningkatan pada Pemberdayaan Karyawan akan diikuti oleh peningkatan Komitmen Organisasional. Hasil pengujian hipotesis menunjukkan bahwa terdapat pengaruh yang negatif dan signifikan variabel Stress Kerja terhadap Komitmen Organisasional pada karyawan Rumah Luwih Hotel Di Keramas Gianyar, yang artinya peningkatan pada Stres Kerja akan diikuti oleh peningkatan Komitmen Organisasional. Hendaknya perusahaan mampu mengadakan kegiatan yang berkaitan dengan pemberdayaan karyawan. Selain hal tersebut bermanfaat dalam rangka meningkatkan komitmen organisasi karyawan dalam sebuah perusahaan, hal tersebut juga bermanfaat untuk merningkatkan kualitas sumber daya manusia dalam sebuah perusahaan. Sehingga pemberdayaan yang diadakan disebuah perusahaan akan meningkatkan produktifitas sebuah perusahaan.

Perusahaan dapat memperbaiki arah kebijakan terkait tugas, wewenang, hak dan kewajiban tenaga kerja (karyawan) agar memiliki job desk yang jelas, menyesuaikan beban kerja karyawan dan melakukan upaya-upaya seperti gathering karyawan, outbond, evaluasi kinerja sebagai bentuk upaya mengelola hubungan baik seluruh stakeholder di perusahaan. Sehingga tingkat stress kerja karyawan dapat menurun sehingga komitmen organisasional karyawan pada perusaaan dapat semain meningkat. Selain itu, pihak manajemen juga diharapkan dapat mengelola stres kerja agar dapat meningkatkan komitmen organisasional karyawan dengan memberikan karyawan pekerjaan yang tidak melebihi daya tahan tubuh, memberikan pekerjaan sesuai dengan job desk yang telah ditentukan. Perusahaan sebaiknya memberikan tenggang waktu yang lebih banyak kepada karyawan untuk menyelesaikan pekerjaannya. Perusahaan sebaiknya memberikan pekerjaan kepada karyawannya sesuai dengan kemampuan yang dimilikinya sehingga tidak menimbulkan beban kerja yang berlebihan. 
Perusahaan sebaiknya mampu memberikan kebutuhan dan fasilitas kerja yang baik dan memadai bagi karyawannya agar karyawan tetap loyal dan memiliki komitmen organisasional yang tinggi kepada perusahaan, serta perusahaan dapat membuat sebuah acara hiburan seperti family gathering, outbound atau upaya hiburan lainnya yang diharapkan mampu menjadi solusi dalam mengelola stress kerja yang dialami karyawan.

Peneliti selanjutnya diharapkan lebih memperluas sampel penelitian untuk memperoleh hasil yang lebih akurat, dan agar item pertanyaan yang digunakan untuk mengukur komitmen organisasional karyawan pada penelitian selanjutnya menggunakan pernyataan yang sesuai dengan standar yang diinginkan perusahaan/organisasi sehingga sesuai dengan hasil ukuran komitmen organisasional karyawan, karena penelitian ini menggunakan indikator komitmen organisasional secara umum saja. Peneliti selanjutnya juga disarankan untuk menambahkan bahasan mengenai pengaruh Pemberdayaan Karyawan dan Stres Kerja yang berguna bagi perusahaan/organisasi sebagai bahan pertimbangan dalam meningkatkan komitmen organisasional karyawan. Penelitian mendatang dapat menambah atau memperluas cakupan penelitian dengan menggunakan objek penelitian yang lebih luas atau melakukan penelitian pada objek industri yang berbeda seperti rumah sakit, industri perbankan, manufaktur dan, lain-lain. Penelitian mendatang juga dapat menyasar responden lain seperti Pegawai Negeri Sipil (PNS) ataupun karyawan pada Badan Usaha Milik negara (BUMN) tidak terbatas hanya pada karyawan swata.

\section{REFERENSI}

Abdullah, A. G. K. bin, Almadhoun, T. Z., \& Ling, Y.-L. (2015). Psychological empowerment, job satisfaction and commitment among malaysian secondary school teachers. Asian Journal of Educational Research, 3(3), 34-42.

Ardana, I. K., Mujiati, N. W., \& Utama, I. W. M. (2012). Manajemen Sumber Daya Manusia (1st ed.). Yogyakarta: Graha Ilmu.

Dewe, P. J., Driscoll, M. P. O., \& Cooper, C. L. (2012). Theories of Psychological Stress at work. Handbook of Occupational Health and Wellness, 1(1), 23-38.

Dewi, I. G. A. D. S., \& Utama, I. W. M. (2015). Pengaruh Emotional Intelligence Leaders, Pemberdayaan Karyawan, dan Dukungan Organisasi terhadap Kepuasan Kerja. E-Jurnal Manajemen Unud, 4(6), 1676-1699.

Diputri, N. P. I. P., \& Rahyuda, A. G. (2016). Pengaruh Keadilan Organisasi, Budaya Organisasi, Pemberdayaan Karyawan terhadap Komitmen Organisasi Pada LPD Desa dat Kerobokan. E-Jurnal Manajemen Unud, 5(3), 1457-1485.

Elnaga, A., \& Imran, A. (2013). The Effect of Training on Employee Performance. European Journal of Business and Management, 5(4), 137- 
147.

Fitriah, \& Sudibya, I. G. A. (2015). Pengaruh pemberdayaan karyawan dan kepuasan kerja terhadap komitmen organisasional sekretariat perusahaan daerah pasar kota denpasar. E-Jurnal Manajemen Unud, 4(11), 3478-3507.

Gunawan, A. W., \& Viyanita, O. (2012). Pemberdayaan Psikologi: Hubungan dengan Kepuasan Kerja dan Komitmen Afektif. Media Riset Bisnis \& Manajemen, 12(1), 1-17.

Harun, H., Salleh, R., Memon, M. A., Baharom, M. N. R., \& Abdullah, A. (2014). Job Satisfaction, Organizational Commitment and Stress among Offshore Oil Job Satisfaction, Organizational Commitment and Stress among Offshore Oil and Gas Platform Employees. Asian Social Science, 10(11), 28-32. https://doi.org/10.5539/ass.v10n11p28

Hasibuan, M. S. P. (2014). Manajemen Sumber Daya Manusia. Jakarta: Bumiaksara.

Iresa, A. R., Utami, H. N., \& Prasetya, A. (2015). Pengaruh Konflik Kerja dan Stres Kerja tehadap Komitmen Organisasional dan Kinerja Karyawan (Studi Pada Karyawan PT. Telekomunikasi Indonesia, Tbk Witel Malang). Jurnal Administrasi Bisnis (JAB), 23(1), 1-10.

Ismail, A. Bin, Mohamad, M. H., \& Mohamed, H. A.-B. (2011). An Empirical Study of the Relationship between Transformational Leadership, Empowerment and Organizational Commitment An Empirical Study of the Relationship between Transformational Leadership, Empowerment and Organizational Commitment. International Journal of Economics and Business Research, 2(1), 89-107. Retrieved from http://www.academicjournals.org/AJBM

Jafari, V., Moradi, M. A., \& Ahanchi, M. (2013). An examination of the relationship between empowerment and organizational commitment (Case study Kurdistan province electric staff). Interdiscipinary Journal Of Contemporary Research In Business, 2(12), 860-868.

Karambut, C. A., \& Noormijati, E. A. T. (2012). Analisis Pengaruh Kecerdasan Emosional, Stres Kerja dan Kepuasan Kerja terhadap Komitmen Organisasional (Studi pada Perawat Unit Rawat Inap RS Panti Waluya Malang). Jurnal Aplikasi Manajemen, 10(3), 655-668. Retrieved from https://jurnaljam.ub.ac.id/index.php/jam/article/view/451/490

Karim, F., \& Rehman, O. (2012). Impact of Job Satisfaction, Perceived Organizational Justice and Employee Empowerment on Organizational Commitment in Semi-Government Organizations of Pakistan. Journal of 
Business Studies Quarterly, 3(4), 92-104.

Kazlauskaite, R., Buciuniene, I., \& Turauskas, L. (2011). Organisational and psychological empowerment in the HRM $\square$ performance linkage. Employee Relations, 34(2), 138-158. https://doi.org/10.1108/01425451211191869

Kristin, Y. S., \& Sadjiarto, A. (2014). Hubungan Profesionalisme, Komitmen Organisasi, Iklim Organisasi, dan Stres Kerja terhadap Kinerja Pegawai Account Representative di KPP Pratama Surabaya Rungkut. Tax \& Accounting Review, 3(2).

Kuo, T., Ho, L., Lin, C., \& Lai, K. (2010). Employee empowerment in a technology advanced work environment. Industrial Management \& Data Systems, 110(1), 24-42. https://doi.org/10.1108/02635571011008380

Meyer, J. P., Stanley, D. J., Herscovitch, L., \& Topolnytsky, L. (2002). Affective, Continuance, and Normative Commitment to the Organization: A Metaanalysis of Antecedents, Correlates, and Consequences. Journal of Vocational Behavior, 61(1), 20-52. https://doi.org/10.1006/jvbe.2001.1842

Mohammadian, M., \& Amirkabiri, A. (2014). A Study Of The Relation Between Empowerment, Job Satisfation, Job Stress And Organizational Commitment: A Case Study Of The Central Office Of Petro Pars Company. Indian J.Sci.Res, 7(1), 855-869.

Muhammad, I. G., \& Abdullah, H. H. (2016). Assessment of Organizational Performance: Linking the Motivational Antecedents of Empowerment, Compensation and Organizational Commitment. International Review of Management and Marketing, 6(4), 974-983.

Parameswari, A. A. A., \& Rahyuda, A. G. (2014). Pengaruh Pemberdayaan Karyawan terhadap Persepsi Keadilan Organisasi dan Komitmen Organisasi (Studi Kasus pada Badan Lingkungan Hidup (BLH) Kabupaten Gianyar, Bali). E-Jurnal Manajemen Universitas Udayana, 3(12), 3781-3800. Retrieved from https://ojs.unud.ac.id/index.php/Manajemen/article/view/10086

Pratiwi, P. (2012). Pengaruh Budaya Organisasi dan Pemberdayaan terhadap Komitmen Organisasional dalam Meningkatkan Kinerja. Jurnal Manajemen Dan Kewirausahaan, 14(1), 41-52.

Putra, I. G. S., \& Wibawa, I. M. A. (2014). Pengaruh Stres Kerja dan Komitmen Organisasi Terhadap Kepuasan Kerja Berdasarkan Gender pada Warong Miyabi Bali. E-Jurnal Manajemen Universitas Udayana, 3(9), 2745-2766. Retrieved from https://ojs.unud.ac.id/index.php/Manajemen/article/view/9319 
Ramdhan, D. (2015). Kepemimpinan Transformasional dan Pemberdayaan Psikologis terhadap Komitmen Organisasi dan implikasinya Kinerja Pegawai. Kontigensi, 3(2), 117-128.

Rismawan, P. A. E., Supartha, W. G., \& Yasa, N. N. K. (2014). Peran Memediasi Komitmen Organisasional pada Pengaruh Stres Kerja dan Kepuasan Kerja terhadap Intensi Keluar Karyawan. E-Jurnal Ekonomi Dan Bisnis Universitas Udayana, 3(8), 424-441.

Suhada, A., Marnis, \& Hamid, L. (2015). Pengaruh Konflik Kerja dan Stres terhadap Komitmen organisasi pada PT United Tractors cabang Pekan Baru. Jom Fekon, 2(1), 1-15. Retrieved from https://jom.unri.ac.id/index.php/JOMFEKON/article/view/7999

Tielung, J. (2013). Pemberdayaan Karyawan, Motivasi dan Komitmen Organisasi terhadap Kinerja Karyawan pada PT. PLN (Persero) Wilayah VII Manado. Jurnal EMBA, 1(4), 1799-1808.

Wadhwa, D. S., \& Verghese, M. (2015). Impact of Employee Empowerment on Job Satisfaction and Organizational Commitment: An Empirical Investigation with Special Reference to Selected Cement Industry in Chhattisgarh. International Journal in Management and Social Science, 3(3), 280-286.

Wibowo, I. G. P., Riana, G., \& Putra, M. S. (2015). Pengaruh Stres Kerja terhadap Kepuasan Kerja Dan Komitmen Organisasional Karyawan. E-Jurnal Ekonomi Dan Bisnis Universitas Udayana, 4(2), 125-145.

Yavuz, M. (2010). The effects of teachers' perception of organizational justice and culture on organizational commitment. Journal of Business Managemen, 4(5), 695-701. Retrieved from http://www.academicjournals.org/AJBM

Yusuf, Y. H. (2013). Pengaruh Tingkat Partisipasi dalam Tim Kerja dan Kompetensi Tehadap Komitmen Organisasional dengan Pemberdayaan Sebagai Variabel Pemediasi (Studi Kasus Pada Dosen PTS di Banda Aceh). Jurnal Ekonomi Manajemen Dan Bisnis, 1(1), 1-26. 